\title{
高速液体クロマトグラフィーによるバナナ中の ビテルタノール分析法
}

(平成 6 年 11 月 8 日受理)

$\begin{array}{lll}\text { 永山敏廣* } & \text { 小林麻紀* } & \text { 塩田寛子* } \\ \text { 伊藤 正子* } & \text { 田村康宏* } & \text { 田村行弘* }\end{array}$

\section{Determination of Bitertanol in Banana by Liquid Chromatography}

\author{
Toshihiro Nagayama, Maki Kobayashi, Hiroko Shioda, Masako Ito, \\ Yasuhiro TAMURA and Yukihiro TAMURA
}

(The Tokyo Metropolitan Research Laboratory of Public Health: 3-24-1, Hyakunin-cho, Shinjuku-ku, Tokyo 169, Japan)

\begin{abstract}
A simple method for determination of bitertanol in banana by high performance liquid chromatography with fluorescence detection was developed. The banana sample homogenate was extracted with acetone. The crude extract was dissolved in $10 \%$ sodium chloride solution and ethyl acetate, then the ethyl acetate layer was concentrated to dryness. The residue was dissolved in $n$-hexane, and this solution was cleaned up with a Florisil ${ }^{\circledR}$ Cartridge. A methanol solution was analyzed by liquid chromatography. Bitertanol was detected at $325 \mathrm{~nm}$ (excitation at $265 \mathrm{~nm}$ ). Recoveries at the $0.1 \mathrm{ppm}$ and $0.5 \mathrm{ppm}$ levels were $93 \%$ with a coefficient of variation of $3.3 \%$, and the detection limit was $0.005 \mathrm{ppm}$ in the samples.
\end{abstract}

(Received November 8, 1994)

Key words: ビテルタノール bitertanol; バナナ banana; 農産物 agricultural products; 高速液体 クロマトグラフィー high performance liquid chromatography; 蛍光検出 fluorescence detection

\section{緒言}

ビテルタノール (bitertanol) は，多くの糸状菌の必須 成分であるエルゴステロールの菌体内生合成を阻害する トリアゾール系殺菌剤である ${ }^{1}$. 我が国においてあ昭和 61 年 4 月に登録され, リンゴ，ナシ，モモ，イチゴなど の果樹などに広く使用されている. 平成 5 年 3 月 4 日に は厚生省告示第 68 号により大麦，アンズ，キュウリな ど 28 種類の作物に $0.05 \sim 3.0 \mathrm{ppm}$ の基準値が設定され た2).

平成 6 年 1 月, 輸入バナナから食品衛生法の規格基準 值（残留基準値） $0.5 \mathrm{ppm}$ を超えるビテルタノールが検 出され，緊急に監視する必要が生じた．厚生省告示第 68 号で官報告示された試験法は，エスプロカルブ，ジェト フェンカルブ，フルトラニルなどの窒素を含む農薬の一 斉分析法であり，3 種類の溶出溶媒を用いたカラムクロ
マトグラフィーなど比較的繁雑な操作が必要で, ビテル タノールのみを対象として迅速に分析するには不適当で ある ${ }^{21}$. 一方, 登録保留基準に係わる環境庁告示の方法は 単一試験法であることから，厚生省告示法に比較しカラ ムクロマトグラフィーが簡易であるが，転溶溶媒にジク ロロメタンを使用し，また，厚生省告示の方法と同様に アルカリ熱イオン型検出器又は高感度窒素・リン検出器 付きガスクロマトグラフを用いる方法であることか ら), 試料由来の窒素含有成分による誤認に留意しなけ ればならず, 精度よく定量する上で熟練を要する，また， その他既報の試験でも, 多くの場合アルカリ熱イオン型 検出器又は高感度窒素・リン検出器付きガスクロマトグ ラフを用いている(4) 6). そこで今回，選択性の高い蛍光 検出器を装着した液体クロマトグラフを用いて, バナナ 中のビテルタノールを簡易に精度良く分析する方法につ いて検討した。

* 東京都立衛生研究所：干169 東京都新宿区百人町 3-24-1 
Sample $50 \mathrm{~g}$ -acetone $200 \mathrm{ml}$ homogenize filter

Filtrate

$$
\begin{aligned}
& \text { evaporate } \\
& -10 \% \mathrm{NaCl} \text { soln. } 100 \mathrm{ml} \\
& \text {-ethyl acetate } 100,50 \mathrm{ml}
\end{aligned}
$$

Ethyl acetate layer

$$
\begin{aligned}
& \text { anhydro. } \mathrm{Na}_{2} \mathrm{SO}_{4} \text { dehydrate } \\
& \text { evaporate to dryness } \\
& \text {-hexane } 5.0 \mathrm{ml}
\end{aligned}
$$

Scheme 1. Analytical procedure for bitertanol

\section{実験方法}

\section{1. 試薬及ひ標準品}

1) ビテルタノール標準品：林純薬工業(株)製 残留 農薬試験用農薬標準品を用いた。

2) 添加回収試験用標準溶液：ビテルタノール標準品 $50.0 \mathrm{mg}$ を正確に量り,メタノールで正確に $50 \mathrm{ml}$ とし て $1,000 \mu \mathrm{g} / \mathrm{ml}$ の標準原液を作製した。この標準原液 $2.5 \mathrm{ml}$ をタノールで正確に $50 \mathrm{ml}$ として $50 \mu \mathrm{g} / \mathrm{ml}$ 溶液を作製した。この溶液を必要に応じ更にメタノール で一定量に希瀵した。

3） $10 \%$ 塩化ナトリウム溶液：蒸留水約 $900 \mathrm{ml}$ に酢 酸エチル約 $100 \mathrm{ml}$ を加え 1 回洗浄した水に, 残留農薬 分析用塩化ナトリウムを $10 \%$ になるように加え, 溶解 後用いた。

4）純水：蒸留水を Milli-Q ${ }^{\circledR}$ 超純水装置（日本ミリポ アリミテッド(株)製）により精製して用いた。

5) Sep-pak ${ }^{\circledR}$ (フロリジル)：日本ウォーターズ・リ ミテッド製 Sep-pak ${ }^{\circledR}$ Plus Florisil ${ }^{\circledR}$ Cartridge

6) その他の試薬：残留農薬分析用又は高速液体ク口 マトグラフ用を用いた。

\section{2. 䒧}

1）液体クロマトグラフ：(株)島津製作所製 LC6AD 型

2) 蛍光検出器：(株)島津製作所製 RF-535 型
3. 分析方法

1）試験溶液の調製

検体 $50 \mathrm{~g}$ にアセトン $200 \mathrm{ml}$ を加え，ホモジナイザー (10,000 回転/分) で 5 分間細砕した後, ケイソウ土を 5 $\mathrm{mm}$ の厚さに敷いたろ紙を用いて吸引ろ過した。 万紙上 の残留物にアセトン $50 \mathrm{ml}$ を加え軽くかく拌した後吸 引ろ過し，万液を合わせ減圧下 (40以下) でアセトンを 留去した。

残留物に酢酸エチル $100 \mathrm{ml}$ 及び $10 \%$ 塩化ナトリウ ム溶液 $100 \mathrm{ml}$ を加え 5 分間激しく振り混ぜた後, 酶酸 エチル層を分取した。水層に酢酸エチル $50 \mathrm{ml}$ を加え, 同様に操作した。酢酸エチル層を合わせ，無水硫酸ナ卜 リウムで脱水した後ろ過し，減圧下で酢酸エチルを留去 した.

得られた残留物に $n$-ヘキサンを加え, 正確に $5 \mathrm{ml}$ と した.この $1 \mathrm{ml}$ を, Sep-pak ${ }^{\circledR}$ (フロリジル)に負荷し, $2 \%$ アセトンー $n$-ヘキサン溶液 $10 \mathrm{ml}$ で洗浄した後, $50 \%$ アセトンーn-ヘキサン溶液 $20 \mathrm{ml}$ で溶出した。 得ら れた溶出液を減圧下で濃縮乾固し，メ夕ノール $1 \mathrm{ml}$ を 加えて試験溶液とした。

これらの操作方法を Scheme 1 に示した.

2) HPLC 測定条件

カラム：(1) COSMOSIL ${ }^{\circledR}$ C18-AR $(4.6 \mathrm{~mm} \phi \times 250$ $\mathrm{mm}$ ，ナカライテスク社製)

(2) SUPELCOSIL ${ }^{\mathrm{TM}}$ LC-ABZ (4.6 $\mathrm{mm} \phi \times$ $150 \mathrm{~mm}$ ，スペルコ社製)

カラム温度： $50^{\circ}$

移動相：(1) アセトニトリルー純水 $(60: 40)$

(2) メタノールーテトラヒドロフランー純水 $(40: 15: 45)$

流速： $1.0 \mathrm{ml} / \mathrm{min}$

検出器: 蛍光分光光度計 (励起波長： $265 \mathrm{~nm}$, 虽光波 長: $325 \mathrm{~nm}$ )

注入量： $10 \mu \mathrm{l}$

\section{結果及び考察}

\section{1. 抽出，精製方法の検討}

1) 抽出方法

試料ひょう取量は, バナナ中でのビテルタノールの残 留量が部位により大きく異なることから7), 単一成分の 分析としてはやや多いが，サンプリング誤差を少なくす るため $50 \mathrm{~g}$ 採取した. また, バナナからのビテルタノー ルの抽出は，一般に行われているアセトンによる抽出を 行った.

アセトンを留去した後, 転溶時に使用する転溶溶媒, 及び塩化ナトリウム溶液の濃度について若干の検討を加 えた. 転溶溶媒は環境への污染の少ない $n$-ヘキサン, シ エチルエーテル, 酶酸エチル及びこれらの混合溶媒につ いて検討した. $10 \%$ 塩化ナトリウム溶液 $100 \mathrm{ml}$ にビテ ルタノール $(10 \mu \mathrm{g} / \mathrm{ml}$ 標準溶液 $0.5 \mathrm{ml})$ を添加し, 各溶 
媒 $100 \mathrm{ml}$ で 5 分間振とうして, 1 回抽出での溶媒への 転溶率を算出したところ, 酢酸エチルが $93 \%$ で最む良 く, 次いでジェチルェーテルの $80 \%$ であった. そこで, 転溶溶媒は酢酸エチルを用いることとした。

次に, 転溶時に使用する塩化ナトリウムの濃度につい て検討を加えた： $2,5,10 \%$ 及び飽和塩化ナトリウム溶 液 $100 \mathrm{ml}$ にビテルタノール $(10 \mu \mathrm{g} / \mathrm{ml}$ 標準溶液 0.5 ml) を添加し, それぞれ酢酸エチル $100 \mathrm{ml}, 50 \mathrm{ml}$ で 2 回抽出した. その結果, ビテルタノールの抽出率は $2 \%$ 塩化ナトリゥム溶液で 95\%, 他はいずれも 96\% 以上で あった. そこで塩化ナトリウムの濃度は, 有機リン系農 薬も同時に抽出できる $10 \%$ 塩化ナトリウム溶液を用い ることとした.

\section{2）精製方法}

カラムクロマトグラフィーにおけるビテルタノールの 溶出は充てん阂の活性度の違いなどから比較的難しく, 試料からの回収率低下の大きな要因となっている. そこ で今回，ビテルタノールを高率で溶出でき，かつ，精製

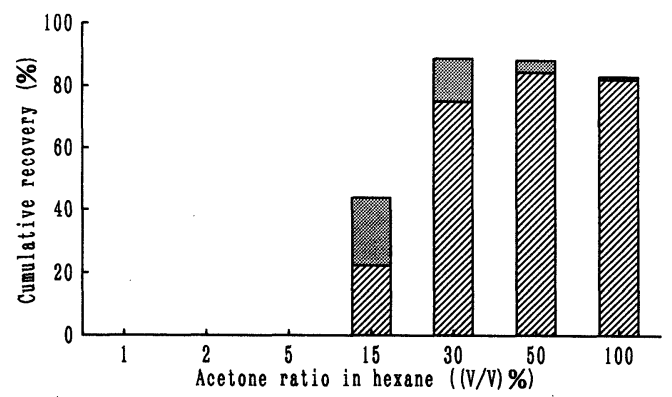

Fig. 1. Elution profile of bitertanol from Sep-pak ${ }^{\circledR}$ cartridge WIIA: bitertanol elution in first $10 \mathrm{ml}$ : bitertanol elution in second $10 \mathrm{ml}$
操作を簡略化する目的で，既製のミニカートリッジカラ ムの利用を試みた。

ビテルタノールの精製には, 厚生省告示及び環境庁告 示のいずれあフロリジルカラムクロマトグラフィーを用 いている2゙). そこで，フロリジルミニカートリッジを用 いて検討を加えた.


に, $n$-ヘキサン, アセトン, ジェチルエーテル, 酢酸エチ ル及びこれらの混液を用いて検討を加えた。 $n$-ヘキサン ではビテルタノールは全く溶出しなかった，また，ジェ チルエーテルのみでは, ビテルタノールのカートリッジ からの溶出率は, ジェチルェーテル $10 \mathrm{ml}$ で $33 \%, 30$ $\mathrm{ml}$ 流出であ $57 \%$ に過ぎなかった. そこで, 酢酸エチ ルージェチルェーテル混液及びアセトンーn-ヘキサン混液 について検討を加えた. カートリッジに保持されたビテ ルタノールは, 酢酸エチルージェチルェーテル混液では


Fig. 2. Fluorescence spectra of bitertanol ${ }^{1)}$ A: excitation spectrum at Em $325 \mathrm{~nm}$ B: emission spectrum at Ex $265 \mathrm{~nm}$ 1) solvent: acetonitrile

Table 1. Elution Rate of Bitertanol from the Column

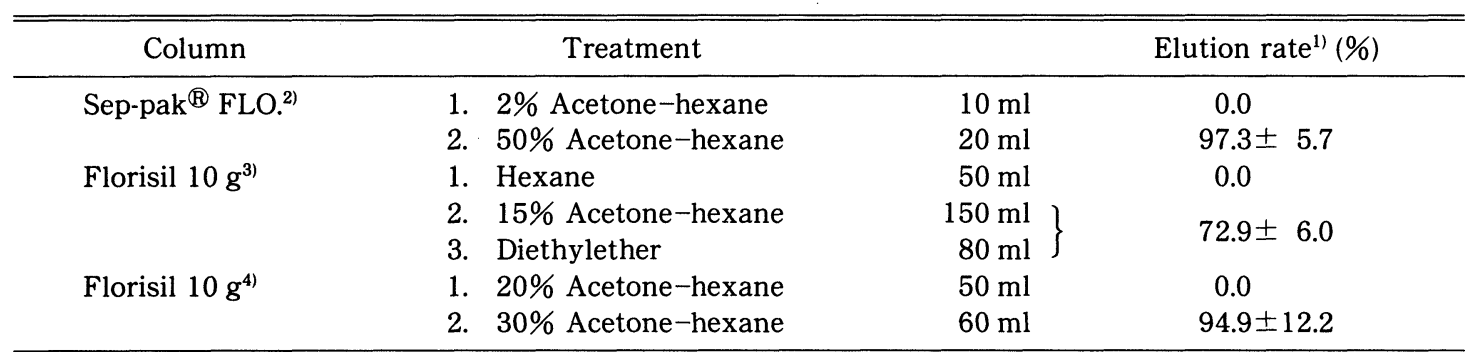

1) $10 \mathrm{ppm}$ Standard solution $0.5 \mathrm{ml}$ added. Indicate average $\pm S$. D. of 3 determinations

2) Sep-pak ${ }^{\circledR}$ Plus Florisil ${ }^{\circledR}$

3) This chromatography was notified in the tolerance for pesticide residue (announced in the official gazette gave notification of Ministry of Health and Welfare).

4) This chromatography was notified in the standard for withholding registration (announced in the official gazette gave notification of the Environment Agency). 
酢酸エチルが $2 \%$ 含有されると溶出し始め, 酢酸エチル 含有量が増加するに従い徐々に溶出率が高くなったのに 比較し, アセトンーn-ヘキサン混液では $30 \%$ 以上アセト ンが含有されると速やかに溶出できた (Fig. 1). そこで, ビテルタノールの精製は, Sep-pak ${ }^{\circledR}$ (フロリジル) を用 い $2 \%$ アセトンーn-ヘキサン混液 $10 \mathrm{ml}$ で洗浄した後, $50 \%$ アセトンーn-ヘキサン $20 \mathrm{ml}$ で溶出することとし た.この精製方法は, 厚生省告示法及び環境庁告示法と 比較し高い割合でビテルタノールを溶出できた（Table 1).

\section{HPLC 条件の検討}

1) 測定波長の検討

蛍光検出器を用いたときの最適測定波長を検討した。 ビテルタノールの励起波長及び蛍光波長を测定し，Fig. 2 に示した. 極大波長は, 図に示したアセトニトリル溶 液で励起 $265 \mathrm{~nm}$, 虽光 $325 \mathrm{~nm}$ 付近であった.この極 大波長はメタノール溶液であ同様であった。

2) 移動相の検討

カラムは市販の ODS カラムを用い, 移動相の検討を 行った.

移動相は I. アセトニトリル一純水混液, II. メタノー ル一純水混液及び III.メタノールーテトラヒドロフラン (THF)－純水混液などについて検討した. ビテルタノー ルは不斉炭素を含む構造を有するため (Fig. 3), 標準品 の注入により通常 2 本のピークが得られる. そこで移動 相の条件として，これらピークを 1 本にまとめて測定で きる方法を検討した。

I 混液のとき，アセトニトリルの含有量が $60 \%$ 以上 で 1 本のピークが得られた. 一方, II 混液では保持時間



Fig. 3. Structure of bitertanol
が長く, III 混液では比較的良好に分離した 2 本のピー クが得られた。 そこで，移動相としては定量計算の容易 な 1 本のピークとして測定できるI混液であるアセトニ トリル一純水 $(60: 40)$ を用いることとした. これらのこ とから, HPLCの測定条件は Table 2 に示したSystem I の条件で行うこととした.

\section{3. ビテルタノールの確認}

本法により, 試料由来の妨害ピークなしに, 測定する ことができた (Fig. 4). しかし, 他の農薬との誤認及び試 料由来の成分との䛊認なども，産地の違いなどにより生 じる可能性もあることから, Table 2 に示した System II の条件で再度 HPLC を行い, ビテルタノールの 2 つ
I



B

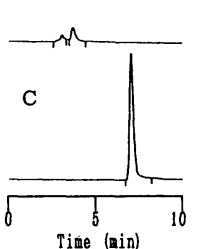

II

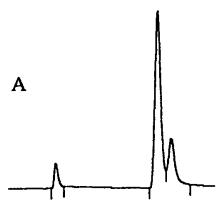

B

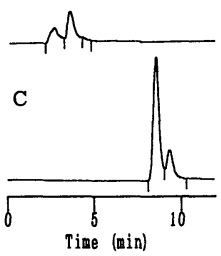

Fig. 4. HPLC chromatograms of bitertanol I: parameters given in text under HPLC operating parameters, Table 2, System I

II: parameters given in text under HPLC operating parameters, Table 2, System II

A: bitertanol residue banana extract

B: banana extract

C: bitertanol standard

Table 2. HPLC Operating Conditions

\begin{tabular}{|c|c|c|}
\hline & System I ${ }^{1)}$ & System $\mathrm{II}^{2)}$ \\
\hline Analytical column & $\begin{array}{c}\text { Cosmosil }{ }^{\circledR} \text { C18-AR } \\
(4.6 \phi \times 250 \mathrm{~mm})\end{array}$ & $\begin{array}{l}\text { Spercosil }^{\mathrm{TM}} \mathrm{LC}-\mathrm{ABZ} \\
(4.6 \phi \times 150 \mathrm{~mm})\end{array}$ \\
\hline Mobile phase & $\begin{array}{l}\text { Acetonitrile-water } \\
(60: 40)\end{array}$ & $\begin{array}{l}\text { Methanol-tetrahydrofran-water } \\
(40: 15: 45)\end{array}$ \\
\hline Column temperature & \multicolumn{2}{|c|}{$50^{\circ}$} \\
\hline Flow rate & \multicolumn{2}{|c|}{$1.0 \mathrm{ml} / \mathrm{min}$} \\
\hline Detect wavelengths & \multicolumn{2}{|c|}{$E x: 265 \mathrm{~nm}, E m: 325 \mathrm{~nm}$} \\
\hline
\end{tabular}

1) For single peak analysis

2) For double peaks analysis 
Table 3. Recovery of Bitertanol Added to Banana

\begin{tabular}{ccc}
\hline \hline $\begin{array}{c}\text { Added }^{1)} \\
(\mu \mathrm{g})\end{array}$ & $\begin{array}{c}\text { Concentration } \\
\text { in sample (ppm) }\end{array}$ & $\begin{array}{c}\text { Recovery } \\
(\%)\end{array}$ \\
\hline 0.5 & 0.01 & $68 \pm 2.1$ \\
5.0 & 0.10 & $94 \pm 2.5$ \\
25.0 & 0.50 & $90 \pm 3.2$ \\
\hline
\end{tabular}

1) Added to $50 \mathrm{~g}$ sample and stand for $30 \mathrm{~min}$.

2) Indicate average $\pm S$. D. of 3 determinations.

のピークを確認することが望ましいと考える。

きゅうり，りんご，いちごなどバナナ以外の試料でも， 本法によりほとんど妨害ピークなしにビテルタノールを 測定できた。 また，小麦や大豆など油脂を多く含む試料 はアセトニトリル分配により脱脂した後, 本法に従いほ とんど妨害ピークなしにビテルタノールを測定できた。 しかし, 妨害ピークが非常に多く, 本法のみでは確認が 困難な試料の場合は, 残りの $n$-ヘキサン試料溶液を更に 環境庁告示のカラムクロマトグラフィーなどで精製した 後，ガスクロマトグラフ-質量分析計を用いて確認する ことが，誤認を防ぐ上で大切であると考える.

\section{4. 添加回収試験結果}

あらかじめビテルタノールを含有していないことを確 認したバナナ $50 \mathrm{~g} に, 1,10$ 及び $50 \mu \mathrm{g} / \mathrm{ml}$ のビテルタ ノール標準溶液をそれぞれ $0.5 \mathrm{ml}$ ずつ加え（試料中濃 度 $0.01,0.10$ 及び $0.50 \mathrm{ppm}$ に相当), 30 分放置した後, 本法に従い試験を行った。 3 回の試行による回収率の平 均値を Table 3 に示した。

試料中添加濃度 $0.01 \mathrm{ppm}$ (添加量 $0.5 \mu \mathrm{g} / 50 \mathrm{~g}$ ）での
回収率は $68 \%$ であったが， $0.10 \mathrm{ppm}$ 及び $0.50 \mathrm{ppm}$ 添 加時では $90 \%$ 以上であり, 良好な回収結果が得られた。 なお，本法における検出限界は $0.005 \mathrm{ppm}$ であった。 まとめ

ビテルタノールの簡易な分析法について検討した。

バナナ中のビテルタノールは，アセトンで抽出し酢酸 エチルに転溶した後, 蛍光検出器付き HPLCにより, 簡 易に精度良く測定できた。 回収率は $0.01 \mathrm{ppm}$ 添加で $68 \%, 0.10 \mathrm{ppm}$ 以上添加で $90 \%$ 以上であった．検出限 界は $0.005 \mathrm{ppm}$ と良好な結果であった。

本法は，簡易な操作で精度良くバナナ中のビテル夕 ノールを測定できることから，実用上大いに役立つと考 える.

\section{文献}

1) 農薬ハンドブック 1992 年版編集委員会編：“農薬ハンド ブック 1992 年版” p. 218 220 (1992) 日本植物防疫協 会.

2）厚生省告示第 68 号：官報（号外第 34 号）“食品, 添加物 等の規格基準の一部を改正する件”平成 5 年 3 月 4 日付 (1993).

3）環境庁告示第 20 号：官報（号外第 53 号）“作物残留に係 る農薬の登録保留基準を改正する件”昭和 61 年 4 月 14 日付 (1986).

4) 外海泰秀, 津村ゆかり, 中村優美子, 伊藤誉志男ら: 食衛 誌. 34, 216 226 (1993).

5) Mendes, M. C. S.: J. Agric. Food Chem. 33, 557 560 (1985).

6) Burden, R. S., Deas, A. H. B., Clark, T.: J. Chromatogr. 391, 273 279 (1987).

7) 永山敏廣, 小林麻紀, 塩田寛子, 伊藤正子, 田村康宏, 田 村行弘：食衛誌。受理. 